\title{
S\&T coverage in English-language Indian dailies
}

\author{
Bharvi Dutt, K.C. Garg
}

\begin{abstract}
The paper examines the coverage of $S \& T$ related items published in selected Englishlanguage Indian newspapers in terms of their quantification and thematic representation. S\&T is not the priority of the English-language newspapers in India. Even sports get several times more coverage than science. There is a case for amply visible representation of science in the press. Health, Environment, Space $S \& T$, and Astronomy were the four dominant subjects covered. Most of the science covered in the newspapers was performed in the US, the UK and other advanced countries of Europe. Among all the newspapers, The Times of India devoted the maximum space to $S \& T$ coverage.
\end{abstract}

\section{Introduction}

Newspapers are one of the oldest and most important channels of mass communication. Despite the onslaught of electronic media, most of the literate people in India still read newspapers and rely on them for information. ${ }^{1}$ Mass media representations are probably the most important, continuing influences shaping perceptions about science and technology (S\&T). ${ }^{2}$ For most people, the reality of science is what they come to know through the mass media, as only a minuscule proportion of the populace in any country is exposed to formal science education. ${ }^{3}$ Most people understand science less through direct experience or past education and more through the filter of journalistic language and imagery. ${ }^{4}$ The media are their only contact with what is going on in rapidly changing scientific and technical fields, as well as a major source of information about the implications of these changes in their lives.

As S\&T has intruded in almost all aspects of our lives today, it is crucial that the populace in the country is aware of developments in this field. S\&T information inputs, for example in the area of health may be of great help in arriving at decisions that are vital to individuals' lives. Such decision making, if based on well informed choices may ultimately prove judicious and beneficial to the individuals, and collectively to society as a whole. Moreover, in democratic societies, awareness about the S\&T issues is vital as S\&T related decisions are taken up by peoples' representatives which have political ramifications at the local, national or international levels, for example nuclear science and technology, organ transplantation, global warming \& climate change, and a wide spectrum of bio-ethical issues, etc. It is here that the role of newspapers as a cost effective tool for disseminating information among the people becomes very critical. Democratic dialogue on scientific matters is crucial to modern societies. ${ }^{5}$

Historically, the English language has been the official working and link language of the Government of India. Those well versed in this language have always commanded awe and authority in the country. Even after more than 60 years of independence, English is still valued as a language of the privileged and powerful, so more and more people in the country intend to acquire the skills of the language and socialize in it. Due to the colonial legacy and the cultural values passed on to the next generations, the fact remains that no other language in the country is endowed with as much value, power, and respect as is the English language. Also, in the recent past, the process of globalisation and liberalization has acted as a catalyst in the rise of English language in India. According to National University for Educational Planning and Administration (NUPEA) the nationwide enrolment in the upper primary section of English-medium schools rose by 74\% during 2004-06. In actual figures, this is a rise from 5.47 million students in 2003 to 9.51 million in 2006 . However, it may be possible that most English medium school registrants are not readers of English-language dailies. Hindi remains the most preferred language for leisure reading $(33.4 \%)$ as well as the principal medium of instruction ${ }^{6}$ (National Youth Readership Survey 2009). 
Public interest in science has increased and the scientific community has become more diversified whereby newer and newer areas of S\&T like nano-science, gene mapping, telemedicine, etc., have emerged. There has also been a re-emergence of infectious diseases coupled with efforts by the scientific community to find their remedies; therefore, one might expect to find a broader and more regular coverage of S\&T related items in the newspapers.

An earlier study conducted by the authors for 1996 English-language dailies estimated less than $1 \%$ of the printed space to S\&T related items. ${ }^{7}$ This study revealed that highest proportion of the space was devoted to nuclear S\&T followed by defence, space S\&T and astronomy. However, this study did not include health related items. Mazzonetto estimated 3\% space to S\&T items in Indian mass media. ${ }^{8}$ Another study made several recommendations for more science representation in Indian media. ${ }^{9}$ Some other studies on S\&T coverage in Indian newspapers were also available but their samples were very small and for short durations. ${ }^{10-12}$

Outside India, a number of researchers have studied different facets of S\&T coverage in newspapers. Massarani et al. ${ }^{13-14}$ has studied science in the press in Latin American countries. Bauer et al. ${ }^{5}$ have examined S\&T coverage in the British Press from 1946 to 1990 . Pellechia ${ }^{16}$ looked into the science coverage in three American newspapers pointing out that methodological and contextual accounts are omitted from the science news. Some other studies on S\&T coverage from other countries are also available in literature (Meadows, ${ }^{17}$ Einsiedel, ${ }^{18}$ Clayton, Hancock-Beaulieu and Meadows, ${ }^{19}$ Metcalfe and Gascoigne, ${ }^{20}$ Buchchi and Mazzolini, ${ }^{21}$ Hijmans $^{22}$ et al, Hyde and King, ${ }^{23}$ Clark and Illman ${ }^{24}$ ).

A cursory look at the English-language national dailies reveals that S\&T related stories encompassing a broad range of scientific and technological issues, which touch peoples' lives at various levels, are allocated space in the newspapers. In view of the above, it is imperative to study the S\&T coverage in English-language newspapers published in India.

\section{Objectives}

The objectives of the study are as follows:

- Quantification of the number of items on S\&T issues published by select newspapers;

- Classification of the above items into broad disciplines, and identification of the disciplines that received maximum attention in terms of the number of items and space devoted to them;

- Identification of newspapers that gave maximum emphasis to S\&T topics;

- Identification of the work place and the sources of the covered items;

- To analyse the prominence of the reported items; and

- Identification of themes, issues, and concerns as reflected by these items.

\section{Data and methodology}

The study was based on the items on S\&T appearing in 37 prominent and popular national English dailies published from metropolitan cities and state capitals. The selected newspapers make up a large proportion of the total circulation. The advantage of selecting prominent and popular dailies has also been pointed out by Moyer and colleagues. ${ }^{25}$ Authors identified the relevant stories and articles (hereafter called "Items") on empirical research in sciences, applied sciences or development, engineering, technology, medicine or health, published in the selected newspapers irrespective of the performing country. Pellechia, ${ }^{26}$ Bader $^{27}$ and Evans ${ }^{28}$ et al have used almost similar definition of science and technology or medicine. Each item was assigned appropriate sub-discipline based on the headline or the content. The content of the item was studied, wherever the headline was ambiguous. The data were collected for a period of six months (April 1, 2008 to September 30, 2008) and was fed into FoxPro software for analysis.

Results. Following paragraphs present the results of the study under different heads.

Items and Space allocated. A total of 5385 items were published on different aspects of S\&T during April 1, 2008 to September 30, 2008, in 37 newspapers published from different parts of India. These items occupied a space of $986,534 \mathrm{~cm}^{2}$. The average space occupied by each item was $183.3 \mathrm{~cm}^{2}($ the 
median value being 140). About $18 \%$ items each were up to $50 \mathrm{~cm}^{2}$ and $51-100 \mathrm{~cm}^{2}$. Thus, one third of the items occupied up to $100 \mathrm{~cm}^{2}$. The maximum number of items was in the range of $101-200 \mathrm{~cm}^{2}$. The remaining 30\% items were scattered in the range higher than $200 \mathrm{~cm}^{2}$. Figure 1 indicates that the number of items gradually reduced with increasing space.

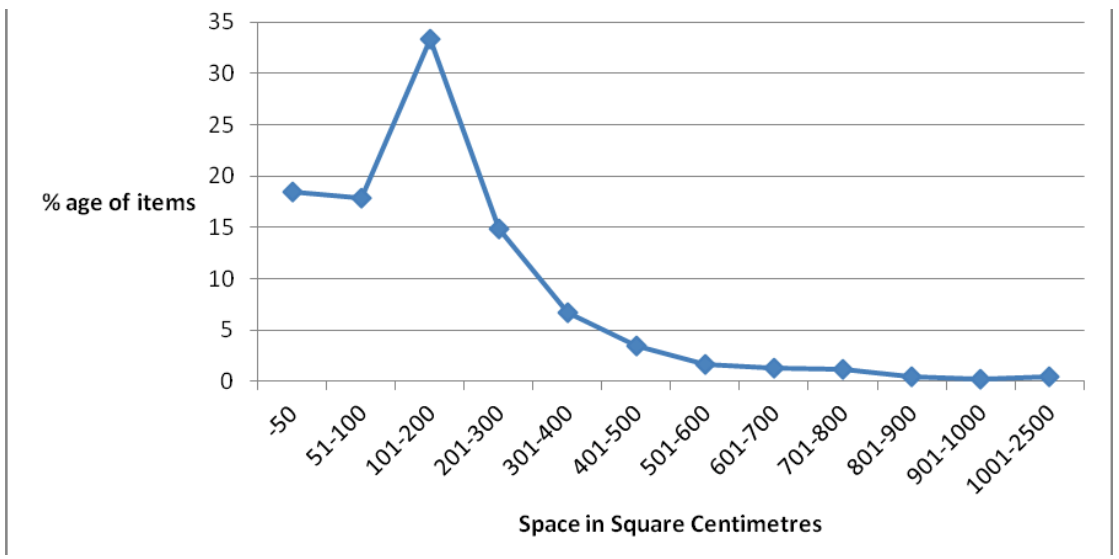

Figure 1. Distribution of items vs. space occupied.

Subjects covered. The maximum space was allocated to items on health $(\sim 37 \%)$ followed by items related to environment $(\sim 15 \%)$ and space S\&T $(\sim 11 \%)$. These three categories occupied about $63 \%$ of space and $67 \%$ of items. The remaining $37 \%$ space was allocated to 13 other sub-disciplines excluding the others. Of all the categories listed in Table 1, the least space was occupied by material science, new technology products, agriculture S\&T, energy, and science communication. These five categories together occupied about $6 \%$ of the total space. Thematic representation of the issues discussed under each sub-discipline is provided in Appendix 1.

\begin{tabular}{|c|c|c|c|c|c|c|c|c|c|c|c|}
\hline \multirow[t]{2}{*}{ \# } & \multirow[t]{2}{*}{ Topic } & \multicolumn{8}{|c|}{ Number of columns } & \multirow[t]{2}{*}{ Total } & \multirow[t]{2}{*}{ Space $\mathrm{cm}^{2}(\%)$} \\
\hline & & I & II & III & IV & $\mathrm{V}$ & VI & VII & VIII & & \\
\hline 1 & Health \& Life sciences & 962 & 680 & 347 & 291 & 119 & 136 & 23 & 15 & 2573 & $360,333(36.5)$ \\
\hline 2 & Environment & 106 & 114 & 119 & 114 & 84 & 54 & 18 & 27 & 636 & $150,699(15.3)$ \\
\hline 3 & Space S\&T & 78 & 80 & 61 & 85 & 47 & 47 & 9 & 10 & 417 & $110,728(11.2)$ \\
\hline 4 & Astronomy & 69 & 53 & 39 & 34 & 19 & 28 & 3 & 3 & 248 & $55,557(5.6)$ \\
\hline 5 & Psychology & 65 & 79 & 54 & 43 & 25 & 24 & 4 & 2 & 296 & $46,640(4.7)$ \\
\hline 6 & Physics & 10 & 13 & 10 & 10 & 13 & 14 & 3 & 4 & 77 & $26,397(2.7)$ \\
\hline 7 & Defence S \& T & 18 & 37 & 15 & 29 & 6 & 7 & 3 & 2 & 117 & $24,867(2.5)$ \\
\hline 8 & Robotics & 9 & 11 & 14 & 18 & 6 & 14 & 1 & 2 & 75 & $20,012(2.0)$ \\
\hline 9 & Animal behaviour & 21 & 14 & 19 & 21 & 10 & 7 & 2 & - & 94 & $17,969(1.8)$ \\
\hline 10 & ICT & 17 & 16 & 12 & 12 & 11 & 10 & 2 & 2 & 82 & $15,676(1.6)$ \\
\hline 11 & Indian S \& T & 5 & 13 & 2 & 9 & 9 & 6 & 1 & 4 & 49 & $15,812(1.6)$ \\
\hline 12 & Science communication & 7 & 11 & 12 & 10 & 5 & 4 & 5 & 2 & 56 & $13,047(1.3)$ \\
\hline 13 & Energy & 8 & 8 & 7 & 7 & 6 & 6 & 2 & 2 & 46 & $12,652(1.3)$ \\
\hline 14 & Agriculture S\&T & 18 & 6 & 5 & 7 & 8 & 6 & 5 & 1 & 56 & $12,504(1.3)$ \\
\hline 15 & New technology products & 14 & 11 & 9 & 11 & 10 & 5 & - & 1 & 61 & $12,329(1.2)$ \\
\hline 16 & Material science & 18 & 15 & 8 & 7 & 11 & - & - & - & 59 & $10,619(1.1)$ \\
\hline 17 & Others* & 120 & 79 & 80 & 67 & 48 & 40 & 5 & 4 & 443 & $89,858(9.1)$ \\
\hline & Total & 1545 & 1240 & 813 & 775 & 437 & 408 & 86 & 81 & 5385 & $986,534(100)$ \\
\hline
\end{tabular}

*Others (15): Earth science, Evolutionary science, Biological science, Nuclear S\&T, Animal science, Automobile engineering, Palaeontology, Aeronautical engineering, Archaeology, Oceanography, Chemical sciences, Forensic science and technology, Food science and technology, Sexology, and Entomology. Include items occupying less than $1 \%$ of space.

Table 1. S\&T news coverage: column spread and space allocation in $\mathrm{cm}^{2}$. 
Placement. The data presented in Table 1 indicated that about two-third of the items was allocated a column spread of up to three columns; the remaining one-third was allocated a column spread of more than three columns. The share of items in one column spread was highest. The proportion of items having a column spread of four and five was almost equal. Of the entire coverage spanning over 5,385 items, $129(2.4 \%)$ items appeared on the first page of the newspapers occupying about $4 \%$ of the total S\&T space across all the newspapers. The majority of these items related to the launch of PSLV, global warming and climate change, genetics, cardiology and neurosciences. Not only were these stories positioned on the front page, about $72 \%$ of these had a column spread of three or more than three columns to arrest the attention of the readers. Two third of these items were supported by visuals.

Newspapers. The total items appeared in 37 newspapers published from different parts of the country. Of these, the national daily The Times of India published from the national capital devoted the maximum space to S\&T items ( 19\%). This was followed by The Asian Age and The Statesman (Table 2). These three newspapers together accounted for about one-third of the space allocated by all the newspapers and about 39\% of the total items. Certain regional newspapers like Shillong Times and Assam Tribune from North Eastern India, Daily Excelsior, Kashmir Times, and Greater Kashmir from Jammu and Kashmir, Nav Hind Times from Goa and Hitavada from Nagpur and Central Chronicle from Bhopal accorded little priority to $\mathrm{S} \& \mathrm{~T}$ related items.

\begin{tabular}{|l|l|l|l|l|l|}
\hline$\#$ & Newspaper & $\begin{array}{l}\text { Number of } \\
\text { items }\end{array}$ & Percentage & Space occupied $\left(\mathrm{cm}^{2}\right)$ & Percentage \\
\hline 1 & Times of India & 1,453 & 27.0 & 189,554 & 19.2 \\
\hline 2 & Asian Age & 409 & 7.6 & 74,567 & 7.6 \\
\hline 3 & Statesman & 211 & 3.9 & 61,182 & 6.2 \\
\hline 4 & DNA & 238 & 4.4 & 55,203 & 5.6 \\
\hline 5 & Mail Today & 162 & 3.0 & 53,229 & 5.4 \\
\hline 6 & Free Press Journal & 361 & 6.7 & 52,726 & 5.3 \\
\hline 7 & Financial Express & 251 & 4.6 & 50,840 & 5.2 \\
\hline 8 & Hindustan Times & 246 & 4.7 & 50,752 & 5.1 \\
\hline 9 & Indian Express & 219 & 4.1 & 45,144 & 4.6 \\
\hline 10 & Hindu & 214 & 4.0 & 43,351 & 4.4 \\
\hline 11 & Pioneer & 113 & 2.1 & 34,532 & 3.5 \\
\hline 12 & Tribune & 202 & 3.8 & 31,535 & 3.2 \\
\hline 13 & Deccan Herald & 299 & 5.6 & 29,207 & 3.0 \\
\hline 14 & Metro Now & 129 & 2.4 & 28,739 & 2.9 \\
\hline 15 & Mumbai Mirror & 125 & 2.3 & 26,945 & 2.7 \\
\hline 16 & Hindu Business Line & 128 & 2.4 & 24,167 & 2.4 \\
\hline 17 & Economic Times & 193 & 3.5 & 22,528 & 2.3 \\
\hline 18 & Mint & 50 & 0.9 & 20,095 & 2.0 \\
\hline 19 & Deccan Chronicle & 83 & 1.5 & 16,609 & 1.7 \\
\hline 20 & Telegraph & 47 & 0.8 & 16,046 & 1.6 \\
\hline 21 & Business Standard & 56 & 1.0 & 15,576 & 1.6 \\
\hline 22 & Political and Business Daily & 56 & 1.0 & 10,256 & 1.0 \\
\hline 23 & Others (15) & 140 & 2.6 & 33,751 & 9.4 \\
\hline & Total & 5385 & 99.9 & 986,534 & 99.9 \\
\hline
\end{tabular}

*Assam Tribune, Bangalore Mirror, Financial World, New Indian Express, Central Chronicle, Daily Excelsior, Financial

Chronicle, Greater Kashmir, Hitavada, Kashmir Times, Mid Day, National Herald, Nav Hind Times, Sentinel, Shillong Times

Table 2. Space allocation to S\&T news items by newspapers.

Sources of items. Of all the reported items, $\sim 42 \%$ did not mention their sources. The remaining 58\% items used indigenous as well as foreign sources. Table 3 presents the distribution of sources for different topics from different countries. Of these, half were indigenous sources and the rest half were foreign. Among the foreign sources, 20 percent were from the UK, $15 \%$ from the US and the rest $23 \%$ were from other countries. Proportion of foreign cited sources was significantly higher than Indian sources for topics 
in the category of environment, space S\&T and astronomy. The indigenous news sources were dominated by Press Trust of India (PTI), Indo-Asian News Service (IANS) and Asian News International (ANI), while foreign news sources were dominated by Reuters (UK), Associated Press (AP) and New York Times (NYT) from USA.

\begin{tabular}{|l|l|l|l|l|l|l|l|l|}
\hline & & $\begin{array}{l}\text { Indian } \\
(\mathrm{I})\end{array}$ & $\begin{array}{l}\text { UK } \\
(\mathrm{II})\end{array}$ & $\begin{array}{l}\text { USA } \\
(\mathrm{III})\end{array}$ & $\begin{array}{l}\text { France } \\
(\mathrm{IV})\end{array}$ & $\begin{array}{l}\text { Others } \\
(\mathrm{V})\end{array}$ & $\begin{array}{l}\text { Sub total } \\
(\mathrm{II} \text { to V) }\end{array}$ & Total \\
\hline 1 & Health \& Life sciences & 841 & 280 & 149 & 93 & 7 & 529 & 1370 \\
\hline 2 & Environment & 134 & 86 & 55 & 53 & 3 & 197 & 331 \\
\hline 3 & Space S\&T & 83 & 43 & 74 & 25 & 8 & 150 & 233 \\
\hline 4 & Astronomy & 58 & 47 & 22 & 16 & 1 & 86 & 144 \\
\hline 5 & Psychology & 128 & 40 & 28 & 12 & 1 & 81 & 209 \\
\hline 6 & Physics & 20 & 12 & 11 & 7 & 1 & 31 & 51 \\
\hline 7 & Defence S \&T & 44 & 2 & 6 & 3 & 1 & 12 & 56 \\
\hline 8 & Robotics & 19 & 5 & 4 & 12 & 1 & 22 & 41 \\
\hline 9 & Animal behaviour & 30 & 17 & 20 & 7 & - & 44 & 74 \\
\hline 10 & Information \& Comm. Tech & 33 & 8 & 15 & 6 & 3 & 32 & 65 \\
\hline 11 & Indian S \& T & 10 & - & - & - & - & - & 10 \\
\hline 12 & Science communication & 15 & 4 & 4 & 1 & - & 9 & 12 \\
\hline 13 & Energy & 8 & 7 & 2 & 2 & 1 & 12 & 20 \\
\hline 14 & Agriculture S\&T & 10 & 7 & 8 & 2 & 1 & 18 & 28 \\
\hline 15 & New technology products & 15 & 7 & 5 & 5 & 1 & 18 & 33 \\
\hline 16 & Material science & 20 & 3 & 3 & 3 & 1 & 10 & 30 \\
\hline 17 & Others & 103 & 72 & 69 & 29 & 2 & 275 & 378 \\
\hline & Total & 1571 & 640 & 475 & 276 & 32 & 1526 & 3097 \\
\hline
\end{tabular}

Table 3. Sources of news items.

Workplace of research. About $78 \%$ of the items mentioned the workplace of research reported in the newspapers. Research originating from 70 countries found place in the newspapers. However, the most dominating countries were USA $(\sim 41 \%)$, India $(\sim 16 \%)$, UK $(\sim 15 \%)$, and Australia (4\%). These four countries accounted for $76 \%$ of those items that had referred to the place of research. Other major performing countries included Germany, Canada, Japan each $\sim 2 \%$, and France, Switzerland, Sweden, and China each $1 \%$.

Visual representations. About $57 \%$ of the items were supported by visuals. Of these, the majority ( $88 \%)$ were single photographs. Other forms of visuals included sketches, diagrams and graphs. A small proportion of items had multiple visuals.

Journal citation. Of all the items, 24\% incorporated journal citations. Out of these, the maximum items $(62 \%)$ pertained to health including life sciences, followed by environment $(7.7 \%)$, psychology $(6.7 \%)$ and astronomy (4.4\%). Other subjects had still fewer journal citations. A large number of different journals had been cited in the items but a few dominant journals included were Nature, Science, Proceedings of the National Academy of Sciences of USA, New Scientist, PLoS, Lancet, Journal of the American Medical Association, Archives of Internal Medicine and New England Journal of Medicine.

\section{Concluding discussion}

Science hardly gets coverage in a prominent position unless it has socio-political ramifications at national or international level. Only a very small proportion of items get front page positioning and even celebration of science, like Bhatnagar award distribution ceremony are rarely covered in the science news. In such a scenario decline of interest in science among Indian students should not be surprising where the presence of science is almost conspicuous by its absence from the potential science-societal interface like popular media, the newspapers.

The study revealed that a wide range of topics were covered by the newspapers. However, the four dominant topics related to the coverage of health, environment, space S\&T, and astronomy need to be 
discussed. Whatever science is covered by the newspapers is overwhelmed by health (including life sciences) related topics as it constituted more than one third of the space and about half of the items. This dominance of health topics was not peculiar to Indian newspapers as similar pattern of coverage is observed in the newspapers published outside India. ${ }^{29-31}$ This may be explicable as people understand those issues easily which directly concern their daily lives than more remote subjects, medicine is always better understood than basic physics. ${ }^{32}$ Also the area of health entails the concept of "need to know". Thus generally health-related information was of interest and of use to the people. However, there exists a bias in the spread of health news particularly HIV/AIDS among men and women. ${ }^{33}$ Next to health related topics environmental issues overwhelmed the coverage. The proliferation of coverage on environment may be due to global political activity raising concern level and interest among the decision makers, policy planners and the populace at large around the world (during the period of coverage). Space S\&T is an issue embedded with state of the art big hi-tech science, involving the prestige and power of the performing country, and has political connotations, so it finds the prominence in the coverage. Since time immemorial astronomical phenomena have aroused the curiosity of the mankind. The distance of several light years of the heavenly bodies of the universe from the life of the human beings on earth, an aura of mystery surrounding the astronomical wonder coupled with the modern science striving to unravel the astronomical phenomena creates enormous interest among the populace and the media in the subject, and thus relatively more items were covered on astronomical topics.

Among all the newspapers, the highest priority to science coverage, both in terms of quantum of items as well as space was accorded by The Times of India. Most of the regional papers were way behind in their coverage. Mainly, the science topics covered in the newspapers were of scientific research performed in the US, the UK and other advanced countries of Europe, whereas Indian research accounted only for $16 \%$ of the items. About half the items mentioned the sources of news. Of these, half were Indian sources, like Press Trust of India, Indo-Asian News Service, and Asian News International, and the remaining foreign sources dominated by the British agency Reuters, followed by American agencies like Associated Press and New York Times, and the French agency AFP. It appeared that Indian Englishlanguage press lacked specialized paraphernalia to report science news and instead found it easier to repackage the information based on the items from the foreign news agencies. Journal citations have also been mentioned in one-fourth of items to lend credence and authenticity about the reported research among the readers. However, the area of health had the highest proportion of journal citations among all other subjects. It seemed that in order to weave the story emphasizing authentic flavor, the reporters took special care to mention the journal publishing the research in health-related topics.

To attract the attention of the readers about half the items had a column spread of three or more than three columns. Visual representation too facilitated in attracting the attention of the readers. More than half the items were supported by a single photograph or some form of visual. However, majority of the items occupied space up to $200 \mathrm{~cm}^{2}$.

Whatever the structure of the coverage in the Indian English-press, it is difficult to avoid saying that science coverage is far from sufficient. It needs to be amply visible to the public to register its presence in the realm of social efforts. There is a case for more science in the newspapers and more science on the front page. The science coverage may not necessarily be a new research finding, it may be anything, like an issue of local or national interest on water quality, or food science, or BT Brinjal, house building, and health care, etc. - the exposure to science behind anything that a common man encounters in quotidian life would indeed help shape peoples' attitude and perception about science besides making them better informed citizens. 


\section{Appendix 1}

\begin{tabular}{|c|c|}
\hline Topics & Sub-topics discussed \\
\hline $\begin{array}{l}\text { Health and life } \\
\text { sciences }\end{array}$ & $\begin{array}{l}\text { Research and development on neurosciences, oncology, genetics, cardiovascular diseases, gynecology } \\
\text { and obstetrics, diabetes, obesity, HIV/AIDS, orthopedics and rheumatology, dermatology, respiratory } \\
\text { diseases, gerontology, sexology, ophthalmology, malaria, tuberculosis, alcoholism, drug abuse, smoking, } \\
\text { dentistry, pediatrics, gastroenterology, virology, urology/nephrology and ENT. The highest space was } \\
\text { occupied by neurology followed by oncology and genetics. }\end{array}$ \\
\hline $\begin{array}{l}\text { Environmental } \\
\text { sciences }\end{array}$ & $\begin{array}{l}\text { Different aspects of climate change and global warming, air pollution, biodiversity, alternative fuels, } \\
\text { carbon emissions and rise in temperature. The share of items in terms of numbers was highest }(8.5 \%) \text { on } \\
\text { climate change and global warming. }\end{array}$ \\
\hline $\begin{array}{l}\text { Space Science and } \\
\text { technology }\end{array}$ & $\begin{array}{l}\text { Space S\&T in India and China, exploration of mars and moon, launch of PSLV and Chandrayan I by India, } \\
\text { and manned space mission by China. Highest number of items was on exploration of mars and moon. }\end{array}$ \\
\hline Astronomy & $\begin{array}{l}\text { Discovery of new stars, new Plutoid, black holes, galaxy clusters and earth like planet in the universe. } \\
\text { Occurrence of celestial event and collision of an asteroid with earth. }\end{array}$ \\
\hline Psychology & $\begin{array}{l}\text { Behavioral aspects, especially of children, couples, teenage girls, and pregnant women, atheistic beliefs } \\
\text { of Indian scientists. }\end{array}$ \\
\hline Physics & Large Hadron Collider (LHC) \\
\hline Defence S\&T & $\begin{array}{l}\text { Successful test firing of Agni missile series, development and launch of Astra and Nag missiles, } \\
\text { successful trial of the Main Battle Tank (Arjuna) and Light Combat Aircraft (LCA). Management aspects } \\
\text { of Defence Research and Development Organization (DRDO). Development of tactical laser, and } \\
\text { variable velocity gun. }\end{array}$ \\
\hline Robotics & $\begin{array}{l}\text { Artificial intelligence, development of advanced walking robot, brain controlled robots, emotional robots, } \\
\text { fire fighting robots, interactive robots, biological and chemical robots, skin like sensitive robots, robots to } \\
\text { invade battle fields and robots for disabled people. Application of robots in disaster management, } \\
\text { surgery, bomb diffusion and house hold work. }\end{array}$ \\
\hline Animal behavior & $\begin{array}{l}\text { Communication among birds and squirrels, loss of bat population and its impact on agriculture, migration } \\
\text { pattern of birds, mating among chimps, intelligence and highly evolved sense among animals, and } \\
\text { cleverness of fishes. }\end{array}$ \\
\hline $\begin{array}{l}\text { Information and } \\
\text { communication } \\
\text { technology }\end{array}$ & $\begin{array}{l}\text { Development of superfast and energy efficient computers, PCs that wake on call, web security, human } \\
\text { computer interaction, in-flight surveillance system for terror detection, software for blind to surf internet, } \\
\text { development of new virus shield, new bug free software and mapping of black holes in the internet. } \\
\text { Development of software for mobile communication, cell phone data tracking, and economics of data } \\
\text { transmission. }\end{array}$ \\
\hline $\begin{array}{l}\text { Indian science and } \\
\text { technology }\end{array}$ & $\begin{array}{l}\text { Declining interest of students in studying science and launching of new schemes to attract students } \\
\text { towards pure sciences, under representation of women in science, decrease in Indian scientific output as } \\
\text { compared to China, plagiarism by Indian scientists, and India's space policy. }\end{array}$ \\
\hline $\begin{array}{l}\text { Science } \\
\text { communication }\end{array}$ & $\begin{array}{l}\text { Popular write-ups on chicken pox virus, thyroid among kids, polycystic ovarian disease, and lack of } \\
\text { awareness on child development \& basic nutritional facts, lunar eclipse, solar eclipse, experiments } \\
\text { performed during solar eclipse, workshop on safely watching the solar eclipse, and act of Venus } \\
\text { disappearing behind the sun. Exhibition on space science, science express exhibition, research } \\
\text { misconduct among scientists, plagiarism by scientists and green Yagana. }\end{array}$ \\
\hline Energy & $\begin{array}{l}\text { Renewable / alternative sources of energy like bio-fuels, solar energy, wind energy, and wave energy etc, } \\
\text { Development of solar cells using nano particles to improve their efficiency and development of } \\
\text { alternative technologies to reduce carbon emissions. }\end{array}$ \\
\hline $\begin{array}{l}\text { Agriculture science } \\
\text { and technology }\end{array}$ & $\begin{array}{l}\text { Genetics research in agriculture science like GM crops such as apple, hybrid variety of maize and paddy, } \\
\text { mapping of cocoa gene, plant mutation, and regulation for growing } \mathrm{GM} \text { crops. growing of vegetables in } \\
\text { zero gravity conditions and sky scrapers, development of sensors to detect } \mathrm{NO}_{2} \text { in soil, land reforms, soil } \\
\text { contamination by sewage, organic fertilizers, growing of bio-fuel crops, and declining budget allocation } \\
\text { for agricultural R\&D in developing countries. }\end{array}$ \\
\hline $\begin{array}{l}\text { New Technology } \\
\text { Products }\end{array}$ & $\begin{array}{l}\text { Development of tiny electron microscope, vehicle anti theft system, interactive class rooms, air cooling } \\
\text { device, better aircraft wings, 3D camera, eye shaped camera, advanced CCTV camera, cancer patient } \\
\text { health care system, device for dissolving dead bodies, infrared night imager, memristors and Gallium } \\
\text { Nitride transistor. }\end{array}$ \\
\hline Material science & $\begin{array}{l}\text { Development of nano materials like magnetic nano fluids, nano material membrane, nano paper, nano } \\
\text { nets, nano wires, synthetic nano plastics, and gold nano particles. Biosensors for cancer detection, cell } \\
\text { based biosensors, novel superconductivity materials, water proof paper, flat mirror, shock absorbent } \\
\text { helmet, solar textile, thinnest leak proof balloon and new invisible material. }\end{array}$ \\
\hline
\end{tabular}




\section{Note and references}

1 G. Raza, B. Dutt and S. Singh (1995), Impact of Plague Epidemic on Public Understanding of and Attitude Towards Health and Hygiene: A Survey of Delhi and Gurgaon Populace, New Delhi, NISTADS-WP-111/95.

2 J. Metcalfe and T. Gascoigne (1995), Science Journalism in Australia, Public Understanding of Science 4: 411-428.

3 D. Nelkin (1990), Selling Science, Physics Today pg. 41-42.

4 Ibid.

5 D. Dickson (2005), The case for a 'deficit model' of science communication, Sci. Dev. Net 28 June 2005.

${ }^{6}$ R. Shukla (2010), Indian Youth Demographic and Readership: Results from the National Youth readership Survey, National Book Trust and National Council of Applied Economic Research.

7 B. Dutt and K.C. Garg (2000), An Overview of Science and Technology Coverage in Indian English-language Dailies, Public Understanding of Science 9: 123-140.

8 M. Mazzonetto (2005), Science Communication in India: Current Situation, History and Future Development, JCOM 04(01): F01.

9 D.M. Salwi (2002), Science in Indian Media: A Blueprint for the New Millennium, New Delhi, Vigyan Prasar.

10 M. Kumar (2005), Coverage of Science \& Technology in National Regional Newspapers: A Comparative Study, Indian Journal of Science Communication 4(2): 7-12.

11 I. Puri (2006), Science and Technology Coverage in Electronic and Print Media: A Case study of Gujarat, Indian Journal of Science Communication 5(2): 3-6.

12 U.K. Arya (2007), Coverage of Research News in Indian Newspapers, Mass Communicator 1(2): 8-20.

13 L. Massarani, B. Buys, L.H. Amorim and F. Veneu (2005), Science Journalism in Latin America: A Case Study of Seven Newspapers in the Region, Journal of Science Communication 04(03): A02.

14 L. Massarani and B. Buys (2007), Science in the Press in Nine Latin American Countries, Brazilian Journalism Research 3(2): 77-96.

15 M. Bauer, A. Ragnarsdottir, A. Rudolfsdottir and J. Durant (1995), Science and Technology in the British Press, 1946-1990: A Systematic Content Analysis of the Press, The Science Museum, London and London School of Economics, London U.K.

16 M.G. Pellechia (1997), Trends in Science Coverage: a Content Analysis of Three US Newspapers, Public Understanding of Science 6(1): 49-68.

17 A.J. Meadows (1991), Quantitative Study of Factors Affecting the Selection and Presentation of Scientific Material to the General Public, Scientometrics 20(1): 113-119.

18 E.F. Einsiedel (1992), Framing Science and Technology in the Canadian Press, Public Understanding of Science 1(1): 89-101.

19 A. Clayton, M. Hancock-Beaulieu and J. Meadows (1993), Change and Continuity in the Reporting of Science and Technology: a Study of the Times and the Guardian, Public Understanding of Science 2(3): 225-234.

20 J. Metcalfe and T. Gascoigne (1995), Science Journalism in Australia, Public Understanding of Science 4(4): 411-428.

21 M. Buchchi and R.G. Mazzolini (2003), Big Science, Little News: Science Coverage in the Italian Daily Press, 1946-1997, Public Understanding of Science 12(1): 7-24.

22 E. Hijmans, A. Pleijter and F. Wester (2003), Covering Scientific Research in Dutch Newspapers, Science Communication 25(2): 153-176.

23 F. Hyde and C. King (2006), What Papers Say: Science Coverage by UK National Newspapers, School Science Review 88(322): 81-84.

24 F. Clark and D.L. Illman (2006), A Longitudinal Study of the New York Times Science Times Section, Science Communication 27(4): 496-513.

25 A. Moyer, S. Greener, J. Beauvais and P. Salovey (1995), Accuracy of Health Research Reported in the Popular Press: Breast Cancer and Mammography, Health Communication 7:147-161

26 M.G. Pellechia (1997), Trends in science Coverage: a Content Analysis of Three US Newspapers, Public Understanding of Science 6(1): 49-68.

27 R.G. Bader (1990), How Science News Section Influence Newspapers Science Coverage, 
Journalism Quarterly 67: 88-96.

28 W.A. Evans, M. Krippendorf, J.H. Yoon, P. Posluszny and S. Thomas (1990), Science in the prestige and national tabloid presses, Social Science Quarterly 71: 105-117

29 M. Bauer, A. Ragnarsdottir, A. Rudolfsdottir and J. Durant (1995), Science and Technology in the British Press, 1946-1990: A Systematic Content Analysis of the Press, The Science Museum, London and London School of Economics, London U.K.

30 D. Nelkin (1995), Selling Science: How the Press Covers Science and Technology, New York, W.H. Freeman and Company.

31 C. van Rooyen, A Report on Science and Technology Coverage in the South Africa Print Media, available at http://www.saasta.ac.za/scicom/pdfs/setcoverage_printmedia.pdf, accessed on November 2011.

32 B.W. Lewenstein (1995), Science and the Media, in S. Jasanoff et al (eds.), Handbook of Science and Technology Studies, Sage Publication.

33 S. Singh, G. Raza, S.N. Misra and P. Dahiya (2009), Mapping Gender Differences in Understanding about HIV/AIDS, JCOM 08(03): A01.

\section{Authors}

Bharvi Dutt is a researcher at CSIR-National Institute of Science Technology and Development Studies (CSIR-NISTADS) and has interests in science communication and research performance evaluation. Over the last more than two decades he has published several research papers in Indian and foreign journals. E-mail: bh_arvi@yahoo.com.

Dr. K.C. Garg works in the area of research performance evaluation and science communication. He has pubblished several articles on different aspects of research performance evaluation and a few in science communication. E-mail: gargkc022@gmail.com.

How TO CITE: $\quad$ B. Dutt and K.C. Garg, S\&T coverage in English-language Indian dailies, Jcom 11(03) (2012) A01. 